\title{
USING THERMOMECHANICAL TREATMENTS TO IMPROVE THE GRAIN GROWTH OF NEW-GENERATION ODS ALLOYS
}

\author{
UPORABA TERMOMEHANSKE OBDELAVE ZA IZBOLJŠANJE \\ RASTI ZRN NOVE GENERACIJE ODS ZLITIN
}

\author{
Omid Khalaj ${ }^{1}$, Hana Jirková ${ }^{1}$, Bohuslav Mašek ${ }^{1}$, Parsa Hassasroudsari¹, Tomáš Studecký ${ }^{2}$, \\ Jiří Svoboda ${ }^{3}$ \\ ${ }^{1}$ University of West Bohemia, Univerzitní 22, 30614 Pilsen, Czech Republic \\ ${ }^{2}$ COMTES FHT a.s., Průmyslová 995, 33441 Dobřany, Czech Republic \\ ${ }^{3}$ Institute of Physics of Materials, Academy of Sciences of the Czech Republic, Žižkova 22, 61662 Brno, Czech Republic \\ khalaj@vctt.zcu.cz
}

Prejem rokopisa - received: 2017-12-15; sprejem za objavo - accepted for publication: 2018-02-15

doi:10.17222/mit.2017.148

\begin{abstract}
In order to achieve specific mechanical properties and structures of a material, a combination of new technologies together with an unconventional use of different types of materials could be an asset. Powder metallurgy, involving a metal matrix and dispersed stable particles, in combination with mechanical alloying and hot consolidation could be a solution. This paper describes the thermomechanical characteristics of new oxide-dispersion-strengthened (ODS) alloys with a Fe-Al matrix in terms of changes in the grain-size distribution. Recrystallization and grain growth were investigated over a range of temperatures and deformations. The results show that the grain-growing process in the new ODS alloys is significantly affected by the thermomechanical treatment, leading to the maximum grain size within $20-\mathrm{h}$ annealing at $1200{ }^{\circ} \mathrm{C}$. They are analysed using different methods, including optical microscopy.

Keywords: grain growth, ODS alloys, steel, $\mathrm{Fe}-\mathrm{Al}, \mathrm{Al}_{2} \mathrm{O}_{3}$

Da bi lahko izdelali materiale s specifičnimi mehanskimi lastnostmi in strukturo, moramo izbirati kombinacijo več različnih novih tehnologij skupaj z nekonvencionalno uporabo različnih vrst materialov. Kot rešitev se ponuja tehnologija metalurgije prahov, s katero lahko ustvarimo mešanico kovinskih prahov in stabilnih oksidnih delcev. Tej sledi kombinacija mehanskega legiranja in vroče konsolidacije. V članku avtorji opisujejo termomehanske lastnosti nove z oksidi disperzijsko utrjene (ODS; angl: Oxide Dispersion Strengthened) zlitine s Fe-Al matrico s poudarkom na spremembah porazdelitve velikosti kristalnih zrn. Avtorji so raziskovali rekristalizacijo in rast zrn v širokem območju temperatur in deformacij. Rezultati raziskave so pokazali, da je proces rasti zrn novih ODS zlitin pomembno odvisen od termomehanske obdelave, ki vodi do maksimalne velikosti zrn po 20 urnem žarjenju na $1200{ }^{\circ} \mathrm{C}$. Avtorji so za analize uporabili različne metode, vključno z optično mikroskopijo.

Ključne besede: rast zrn, $\mathrm{z}$ oksidi disperzijsko utrjene zlitine (ODS), jeklo, Fe-Al, $\mathrm{Al}_{2} \mathrm{O}_{3}$
\end{abstract}

\section{INTRODUCTION}

Historically, oxide-dispersion-strengthened (ODS) alloys have been employed to improve mechanical properties at high temperatures. The first preparation of ODS alloys was reported by W. D. Coolidge in 1910, as a result of using classical powder metallurgy to develop a tungsten-based alloy reinforced with thorium oxides to increase the life span of a tungsten-filament lamp and impede high-temperature grain growth. ${ }^{1}$ Continuing this initial development, several other applications based on various metallic matrices such as aluminium or nickel were implemented over the decades. J. S. Benjamin at the International Nickel Company (INCO) laboratory designed a new process based on high-energy millingpowder metallurgy - later called mechanical alloying. ${ }^{2}$ He developed this process to obtain a homogeneous oxide dispersion within a nickel matrix to produce hightemperature-resistant materials for gas-turbine applications. ${ }^{3}$ Currently, mechanical alloying is still considered to be one of the most effective processes for obtaining fine and homogeneously distributed particles.
In 1829, Félix Savart tried to reproduce the anisotropy effect on various metal specimens to demonstrate that metals consisted of crystallized parts with different orientations. ${ }^{4} \mathrm{He}$ also recorded the first signs of a structural change after deformation while treating modified anisotropic properties of metals. ${ }^{5}$ Continuing the improvement in the ODS-alloy microstructure, H. C. Sorby ${ }^{6}$ reported the formation of an equiaxed grain structure during the annealing of elongated grains in deformed iron by introducing a metallographic technique called recrystallization. In the early 1920s, Carpenter and Elam, followed by Altherthum, clearly established that while the grain-boundary energy provides the driving force for grain growth, the stored energy provides the driving force for recrystallization. Deformation is then clearly established as the initiating process for recrystallization. Despite these fundamental discoveries, recrystallization and grain growth had not yet been distinguished as separate processes.

The proportion of dispersed spherical oxides with a mean size of 5-30 nm (typically) in a mixture is usually below $1 \%$; however, it plays the main role in the stabi- 
lity of the microstructure. The resistance to the coarsening of oxides is much higher in coarse-grained ferrite than in the $\gamma^{\prime}$-precipitates in super alloys. Also, for a mean size of 20-30 nm, the limiting temperature for a long-term operation is between $1000{ }^{\circ} \mathrm{C}$ and $1100{ }^{\circ} \mathrm{C}$. So, it is clear that oxides are extremely stable and the microstructural stability of ODS alloys is much higher than that of nickel-based super alloys. However, the loss of mechanical properties due to the coarsening of oxides was also reported for fine-grained ODS steels at temperatures of about $800{ }^{\circ} \mathrm{C}$ for systems with extremely fine oxide dispersion (about $5 \mathrm{~nm}$ ). ${ }^{7}$ Thus, it is clear that the size of oxides and the grain size have important roles in the stability of a microstructure. Coarser oxides are much more stable than fine ones, which is in line with the cubic law of coarsening kinetics. ${ }^{8-12}$ The mechanically alloyed powder is then consolidated at high temperatures and pressures to produce bulk material in the form of a bar or tube stock. Subsequently, different thermomechanical treatments are applied to optimize its microstructure and mechanical properties. The processing temperatures are critical during the consolidation step in order to retain the nanocrystalline structure generated during the mechanical alloying and to impede particle coarsening and grain growth. ${ }^{13-19}$

In the present study, the ODS alloys consist of a ferritic Fe-Al matrix strengthened with about $7 \%$ volume fraction of $\mathrm{Al}_{2} \mathrm{O}_{3}$ particles. In order to investigate these new groups of materials with a more detailed analysis, this paper concentrates on the mechanical properties of ODS alloys, the microstructure and the phenomenon of recrystallization, leading to an evaluation of the grain growth.

\section{EXPERIMENTAL PART}

\subsection{Material preparation}

The method for producing Fe-Al based ODS alloys with fine $\mathrm{Al}_{2} \mathrm{O}_{3}$ precipitates is highly dependent on powder metallurgy (Figure 1). ${ }^{20}$ In the first step, the powders consisting of $\mathrm{Fe}-11 \%$ mass fraction of the $\mathrm{Al}$ matrix (90\% mass fraction of Fe and $10 \%$ mass fraction of $\mathrm{Al}$ ) are mixed with $1 \%$ mass fraction of $\mathrm{O}_{2}$ in gas, which is absorbed, in a low-energy ball mill developed by the authors, allowing evacuation and filling by oxygen. It is equipped with two steel containers (each $24 \mathrm{~L}$ ), filled with 160 (80 in each) steel balls with a diameter of $40 \mathrm{~mm}$. The mill-rotation frequency can be adjusted between $20 \mathrm{~min}^{-1}$ to $75 \mathrm{~min}^{-1}$. However, for this study, all the material preparation is done at a constant rate of $75 \mathrm{~min}^{-1}$. After the mechanical alloying, the powder changes to a solid solution and is poured from the milling container into a 70-mm-diameter steel container (made of low-alloy steel), evacuated with a suction pump (degassed) and sealed by welding. Then it is heated to a temperature of $750{ }^{\circ} \mathrm{C}$ and rolled in a hot rolling mill to a thickness of $20 \mathrm{~mm}$. In the final step, it is heated again up to a temperature of $900{ }^{\circ} \mathrm{C}$ and rolled to a thickness of $8 \mathrm{~mm}$. An approximately 6-mm-thick ODS sheet, covered on both sides with 1-mm-thick scale from the rolling container, is produced in this way. Afterwards, the specimens are cut with a water jet (Figure 2).

In this study, two types of material $(\mathrm{Fe}-10 \%$ mass fractions of the $\mathrm{Al}$ ferritic matrix with different particle sizes and $7 \%$ volume fractions of $\mathrm{Al}_{2} \mathrm{O}_{3}$ ) were chosen, as described in Table 1. It should be noted that the oxides $\left(\mathrm{Al}_{2} \mathrm{O}_{3}\right)$ were produced with internal oxidation as shown in Figure $\mathbf{1}$ and were not added manually.

Table 1: Material parameters

\begin{tabular}{|c|c|c|c|c|c|}
\hline $\begin{array}{c}\text { Material } \\
\text { No. }\end{array}$ & $\begin{array}{c}\text { Material } \\
\text { type }\end{array}$ & $\begin{array}{c}\text { Milling } \\
\text { time } \\
\text { (hours) }\end{array}$ & $\begin{array}{c}\text { Ferritic } \\
\text { matrix }\end{array}$ & $\begin{array}{c}\text { Volume } \\
\% \text { of } \\
\mathrm{Al}_{2} \mathrm{O}_{3}\end{array}$ & $\begin{array}{c}\text { Typical } \\
\text { particle } \\
\text { size (nm) }\end{array}$ \\
\hline 1 & $\begin{array}{c}\text { ODS } \\
\text { Alloy }\end{array}$ & 245 & $\mathrm{Fe} 10 w / \% \mathrm{Al}$ & 7 & $20-50$ \\
\hline $2^{*}$ & $\begin{array}{c}\text { ODS } \\
\text { Alloy }\end{array}$ & 245 & $\mathrm{Fe} 10 w / \% \mathrm{Al}$ & 7 & $20-50$ \\
\hline
\end{tabular}

* Different rolling force

\subsection{Specimen preparation}

All the prepared containers were annealed at $1000{ }^{\circ} \mathrm{C}$ over $16 \mathrm{~h}$. After normal cooling at room temperature, all
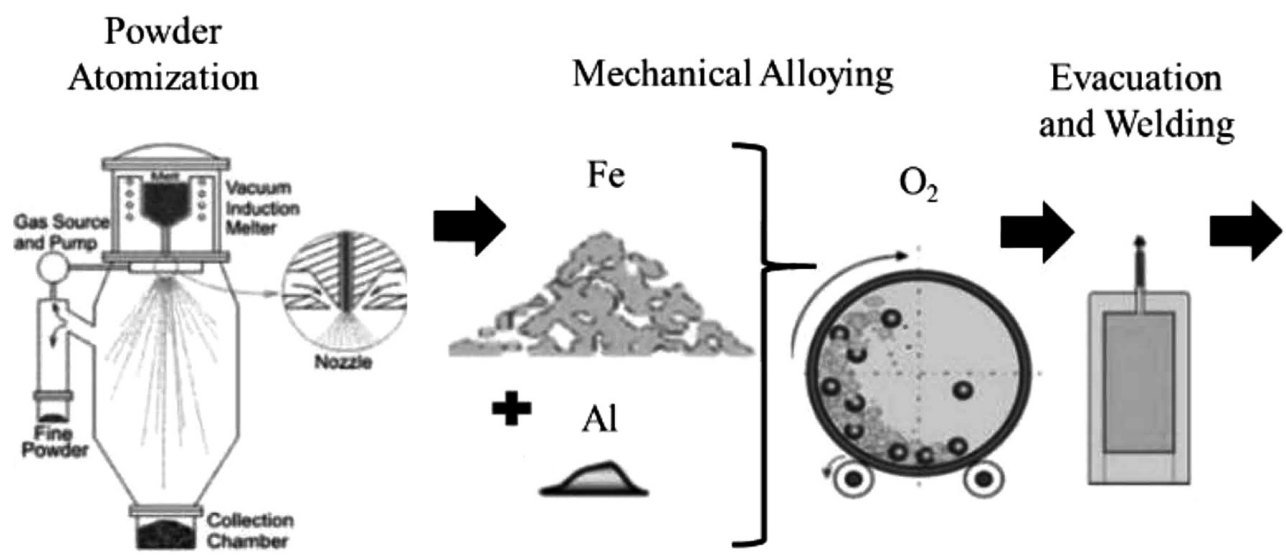

Hot Rolling and Welding

Figure 1: Material-preparation process 


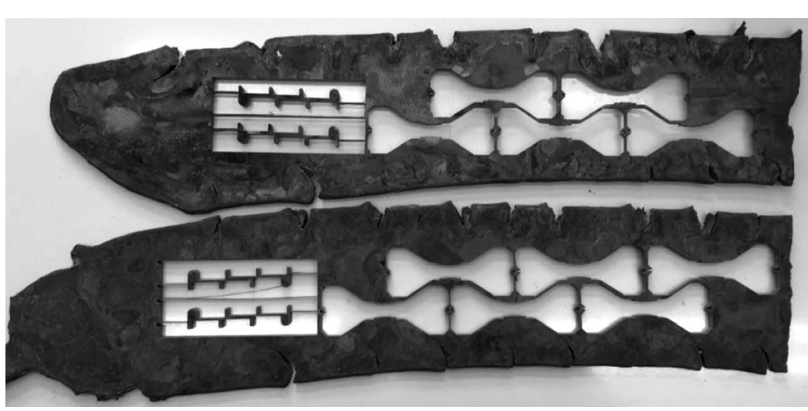

Figure 2: Position of the specimens on a rolled semi-product

the specimens were cut with a water jet in the longitudinal direction (Figure 2) and then all the specimens were removed from the steel containers. The thickness of the specimens was approximately $6 \mathrm{~mm}$ after the grinding. Two specimen types (Figure 3) were selected. Type 1 was used to investigate homogeneous temperature fields, and type 2 for the simplicity of the tests. Specimen type 2 was designed to have 4 different deformations (5, 8,20 and 50) \% at the same time. The shortest part (9 $\mathrm{mm}$ ) was equal to $0 \%$ deformation during the pressing and the other parts had appropriate values of deformation. In order not to apply more deformation than required, the specimens were held in a hydraulic forging press with two 10-mm-thick positioning side plates.

\subsection{Testing equipment}

A hydraulic forging press and a servo-hydraulic MTS thermomechanical simulator were used to carry out the experimental tests. The forging machine was programmed to apply constant pressure at a constant rate to all the samples. In order to find the conditions leading to the most effective grain coarsening by recrystallization, the thermomechanical simulator was used to apply various temperature-deformation paths. It also allowed a combination of tensile and compressive deformation, thus accumulating a high plastic deformation (and a high dislocation density) in the specimens. An Olympus GX51 light microscope was used for the metallographic analysis of the samples. Cross-sections of the samples were prepared using the standard grinding and polishing processes and the microstructure was highlighted with $3 \%$ Nital etching.

\subsection{Testing programme}

The test programme was divided into two different parts. The tests are summarized in Table 2.
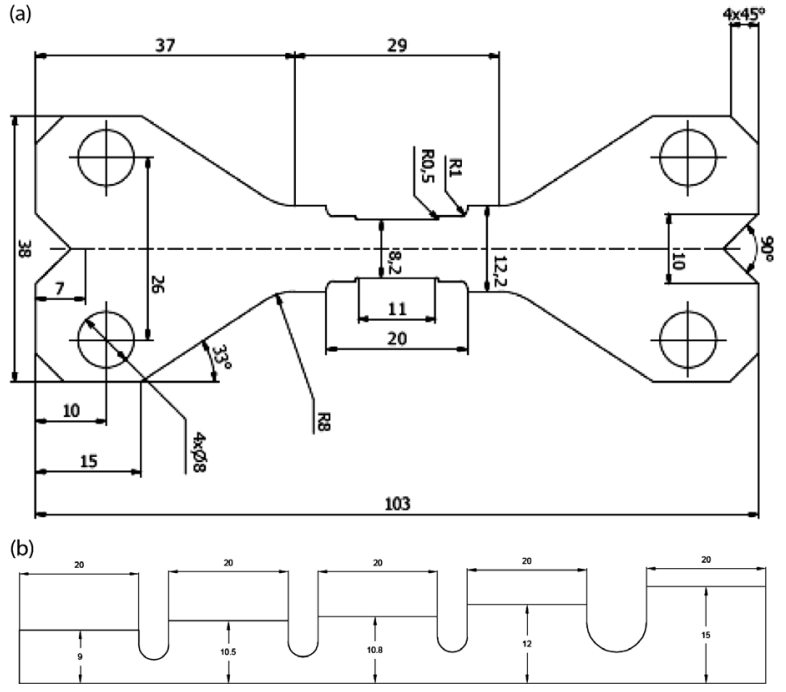

Figure 3: Specimen dimensions in mm: a) type 1, b) type 2

The tests for group A were carried out to investigate the thermomechanical behaviour at different temperatures (treatment no. 1), performing a single tensile test with a constant strain rate of $10^{-3} \mathrm{~s}^{-1}$ (Figure 4). Treatment no. 1 was designed to evaluate the thermomechanical properties of both materials at different temperatures. The test started with the heating up of a sample to the desired temperature in $5 \mathrm{~min}$ and then tension with a strain rate of $10^{-3} \mathrm{~s}^{-1}$ up to the failure of the sample was applied. Then the specimen was left to cool down to room temperature.

The tests for group B were performed to investigate the effects of the holding time at $1200{ }^{\circ} \mathrm{C}$ and the deformation percentage for both materials on the recrystallization and grain coarsening of the type- 2 specimens (Figure 3b). As mentioned above, four different types of deformation $(5,8,20$ and 50) \% were applied as part of treatment no. 2 (Figure 5). During this treatment, the specimens were heated to $1200{ }^{\circ} \mathrm{C}$ in 5 minutes and

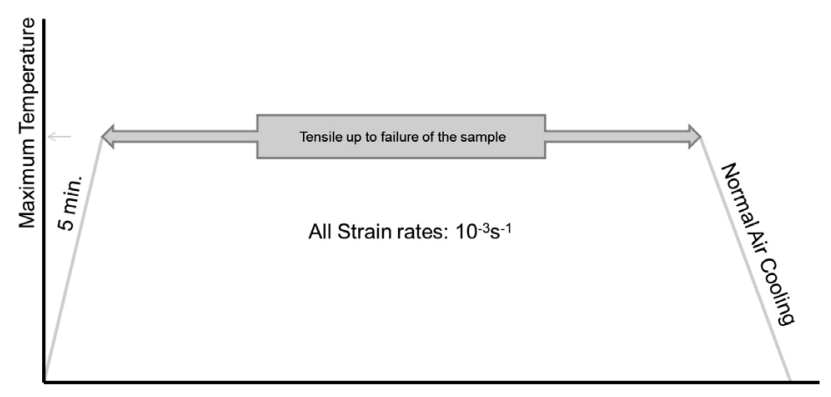

Figure 4: Treatment no. 1

Table 2: Parameters of test programme

\begin{tabular}{|c|c|c|c|c|c|c|}
\hline Test group & Material no. & $\begin{array}{c}\text { Treatment } \\
\text { no. }\end{array}$ & $\begin{array}{c}\text { Holding time } \\
(\mathrm{h})\end{array}$ & $\begin{array}{c}\text { Maximum } \\
\text { temperature } \\
\left({ }^{\circ} \mathrm{C}\right)\end{array}$ & $\begin{array}{c}\text { Number of } \\
\text { tests }\end{array}$ & Purpose of tests \\
\hline A & 1,2 & 1 & - & $\begin{array}{c}1200,1000, \\
800, \mathrm{RT}\end{array}$ & 8 & Investigation of thermomechanical behaviour \\
\hline
\end{tabular}




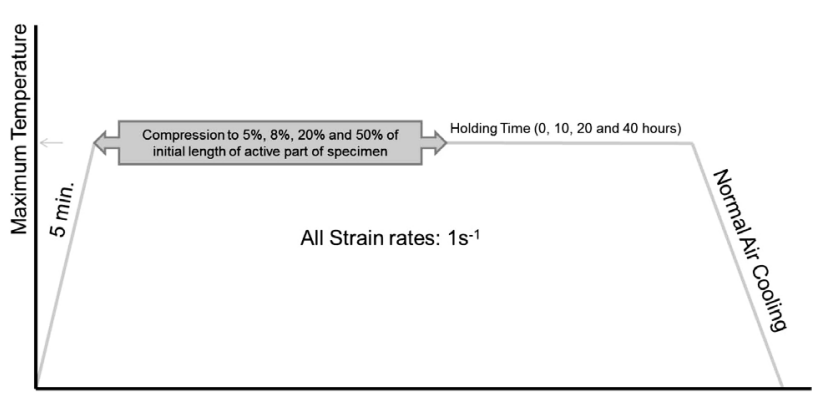

Figure 5: Treatment no. 2

immediately after that the deformation was applied. Subsequently, one specimen of each material was quenched in water for immediate cooling (0-h holding time) and the rest were kept in the furnace for three different holding times of $(10,20,40) \mathrm{h}$, after which they were cooled slowly to room temperature.

\section{RESULTS AND DISCUSSION}

\subsection{Test group $A$}

Figure 6 shows the tensile stress-strain curves for both materials at different temperatures corresponding to treatment no. 1 .

A comparison of the curves for Material 1 from Figure 6a shows that the modulus of elasticity $(E)$ decreases from $8.6(R T)$ to $1.3 \mathrm{GPa}\left(1000{ }^{\circ} \mathrm{C}\right)$ with the increasing
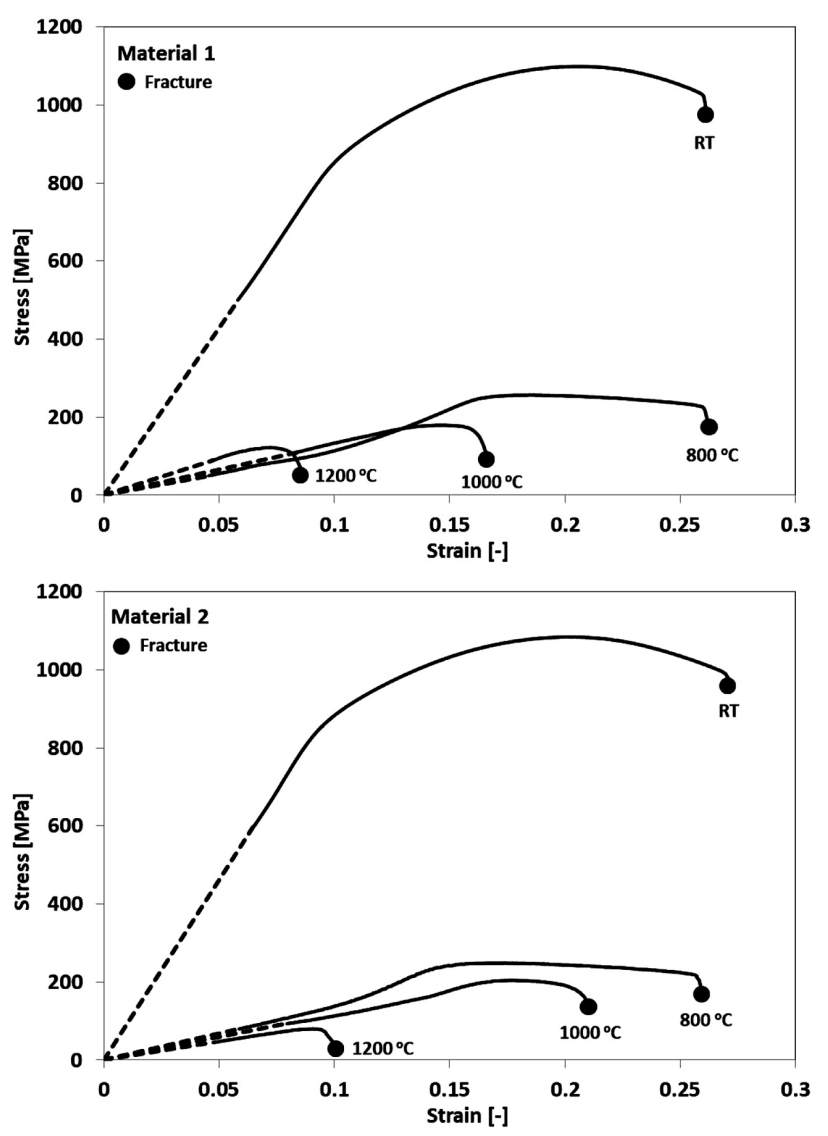

Figure 6: Tensile stress-strain curves for: a) material 1, b) material 2 temperature, to almost $19 \%$ of the initial value at RT. Similarly, the ultimate tensile strength (UTS) decreases from $1100 \mathrm{MPa}(R T)$ to $180 \mathrm{MPa}\left(1000{ }^{\circ} \mathrm{C}\right)$ which shows an almost $86 \%$ reduction from the initial value at RT. Figure $6 \mathbf{b}$ shows a similar trend for Material 2. At $1000{ }^{\circ} \mathrm{C}$, the UTS and $E$ decrease by $86 \%$ and $87 \%$, respectively, in comparison with RT. The work-hardening rate also varies with the temperature, the amount of strain and the composition of the ODS alloy. At lower temperatures, the curve slopes (the modulus of elasticity) are relatively steep from the onset of the plastic deformation to the maximum load. Steep drops in the region between the maximum tensile strength and the fracture point are related to the necking of the specimens.

Table 3 shows the mechanical parameters for both materials from the tensile tests. It can be seen that at the same temperatures, there is a slight difference between the curves of the slopes $(E)$ for each material. It could be that the active energy required for the flow is not simply a function of the applied stress, but rather a complex function involving different factors like the stress, the temperature and the size of the flow units activated by the temperature.

Table 3: Mechanical properties based on the tensile tests

\begin{tabular}{|c|c|c|c|c|}
\hline Material no. & $\begin{array}{c}\text { Tempera- } \\
\text { ture }\left({ }^{\circ} \mathrm{C}\right)\end{array}$ & $\begin{array}{c}E \\
(\mathrm{GPa})\end{array}$ & $\begin{array}{c}U T S \\
(\mathrm{MPa})\end{array}$ & $\begin{array}{c}\text { Elongation } \\
(\%)\end{array}$ \\
\hline \multirow{3}{*}{1} & $\mathrm{RT}$ & 8.6 & 1099 & 14.68 \\
& 800 & 1.1 & 257 & 10.80 \\
& 1000 & 1.3 & 180 & 8.95 \\
& 1200 & 1.9 & 122 & 5.08 \\
\hline \multirow{3}{*}{2} & $\mathrm{RT}$ & 9.2 & 1084 & 16.54 \\
& 800 & 1.4 & 249 & 12.45 \\
& 1000 & 1.1 & 204 & 7.78 \\
& 1200 & 1.0 & 80 & 5.62 \\
\hline
\end{tabular}

It can be seen that the UTS of each material decreases as the test temperature increases. It is almost the same for both materials at RT and $800{ }^{\circ} \mathrm{C}$; however, with further increases in the testing temperature, the difference between both materials increases, which could be attributed to strain aging. Like the UTS, the elongation of both materials increases with the decreasing testing temperature. It is obvious that the total elongation decreases gradually from RT to $800{ }^{\circ} \mathrm{C}$; however, when the temperature is increased to $1200{ }^{\circ} \mathrm{C}$, it jumps to almost $50 \%$ of the initial value at RT for both materials. On the other hand, at higher temperatures, the recovery and damage induced by the creep lead to a decrease in the ductility. ${ }^{21-22}$

\subsection{Test group $B$}

Figure 7 shows the hardness (HV10) test results for both materials without deformation and after the applications of $(5,8,20$ and 50) \% deformation, and at different annealing times of $(0,10,20$ and 40$) \mathrm{h}$ at $1200{ }^{\circ} \mathrm{C}$. A Vickers hardness test was performed using a ZWICK/ 
Material 1

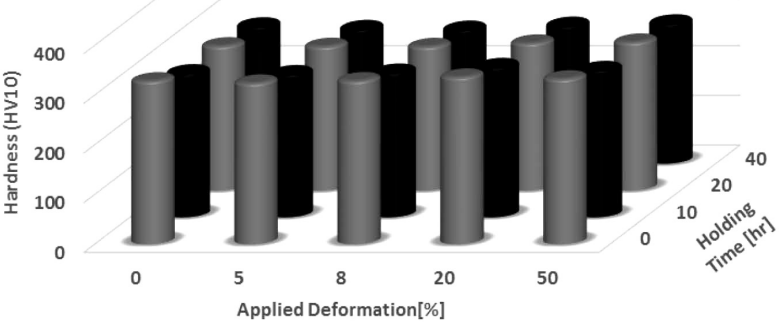

Material 2

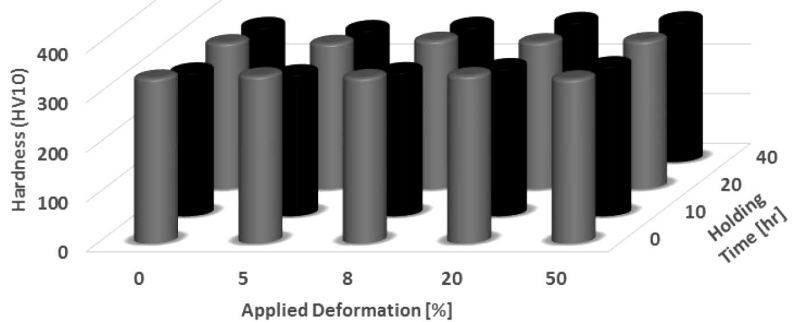

Figure 7: Hardness (HV10) for: a) material 1, b) material 2

ROELL Z2.5 hardness tester with a load of $10 \mathrm{~kg}$ and a loading time of $11 \mathrm{~s}$ on the surfaces of polished samples. The average value was calculated from three measurements.

It can be seen that with the increasing deformation, there is almost no change in the hardness of either material for any of the holding times. On the other hand, with an increase in the applied deformation from $0 \%$ to $8 \%$, the hardness decreases slightly at all the annealing times. However, with the increase from $20 \%$ to $50 \%$, it increases slightly at all the holding times. The hardness values vary from 328 to $332 \mathrm{HV} 10$ (material 1) and 332 to 331 HV10 (Material 2), with no annealing, in the deformation span of 0-50 \%. In a similar way, they vary from 277 to $283 \mathrm{HV} 10$ (Material 1) and 274 to 286 HV10 (material 2), for the 40 -h holding time at $1200{ }^{\circ} \mathrm{C}$ in the deformation span of $0-50 \%$. It is clear that the decrease in the hardness from $0 \%$ to $8 \%$, at $1200{ }^{\circ} \mathrm{C}$, is almost $2 \%$; however, the increase from $8 \%$ to $50 \%$ is maximum, $4 \%$. It can be generally negligible as the difference between the hardness values is small. However, this small fluctuation can be attributed to the occurrence of a dislocation annihilation or rearrangement followed by a rapid subgrain growth; however, this could be due to the inhomogeneity of the material within the whole container.

Figures 8-15 show the microstructures of both materials without deformation and after $50 \%$ deformation for different annealing times of $(0,10,20$ and 40) $h$ at $1200{ }^{\circ} \mathrm{C}$. The light microscope was used to record the microstructure at the grain and subgrain scale for all the deformations $(0,8,20$ and 50) \%; however, due to a large number of images, only those depicting the $0 \%$ and $50 \%$ deformations are presented. The structure con-
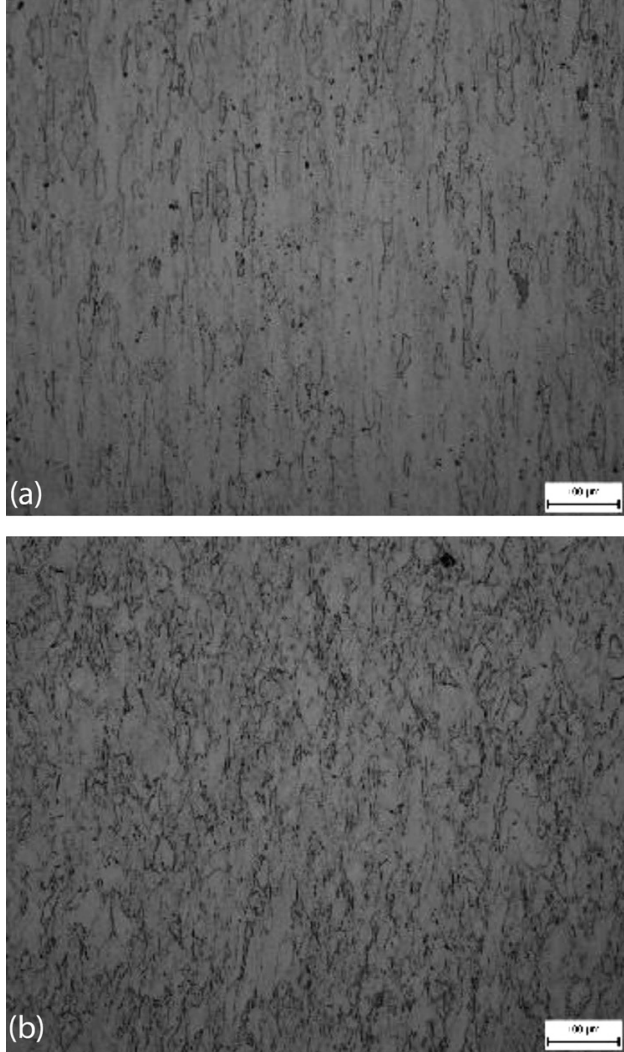

Figure 8: Microstructure for material 1 without annealing: a) without deformation, b) with $50 \%$ deformation
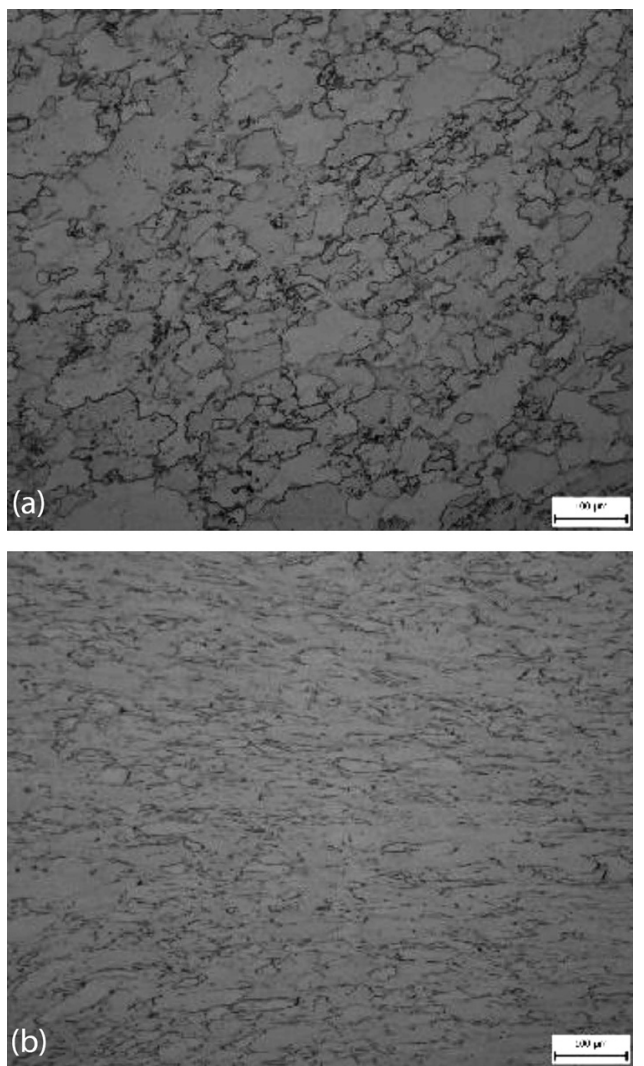

Figure 9: Microstructure of material 2 without annealing: a) without deformation, b) with $50 \%$ deformation 
O. KHALAJ et al.: USING THERMOMECHANICAL TREATMENTS TO IMPROVE THE GRAIN GROWTH ...
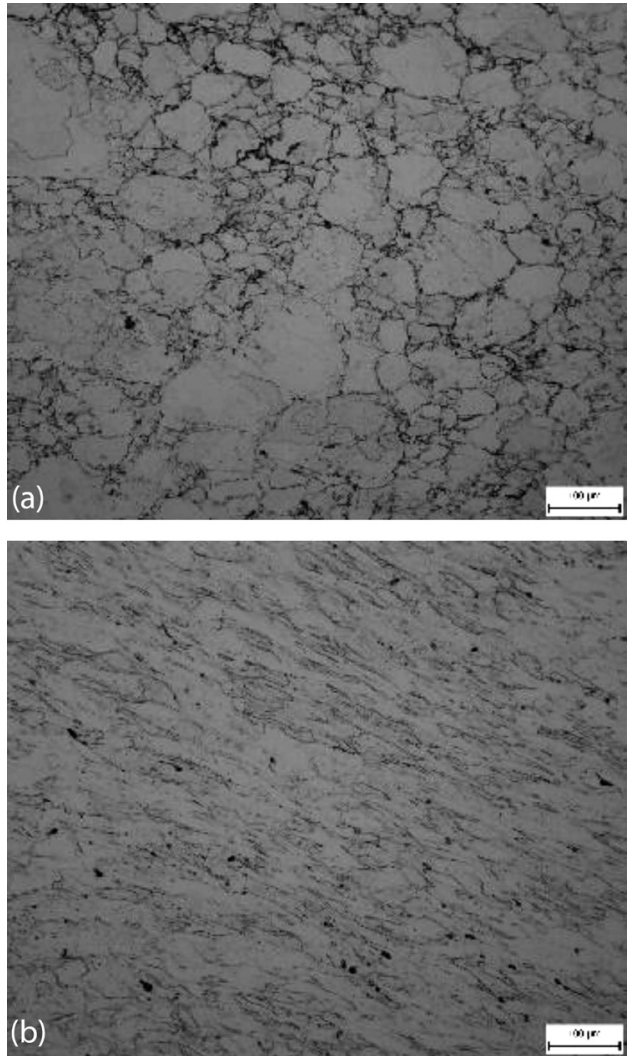

Figure 10: Microstructure for material 1 after $10 \mathrm{~h}$ annealing: a) without deformation, b) with $50 \%$ deformation
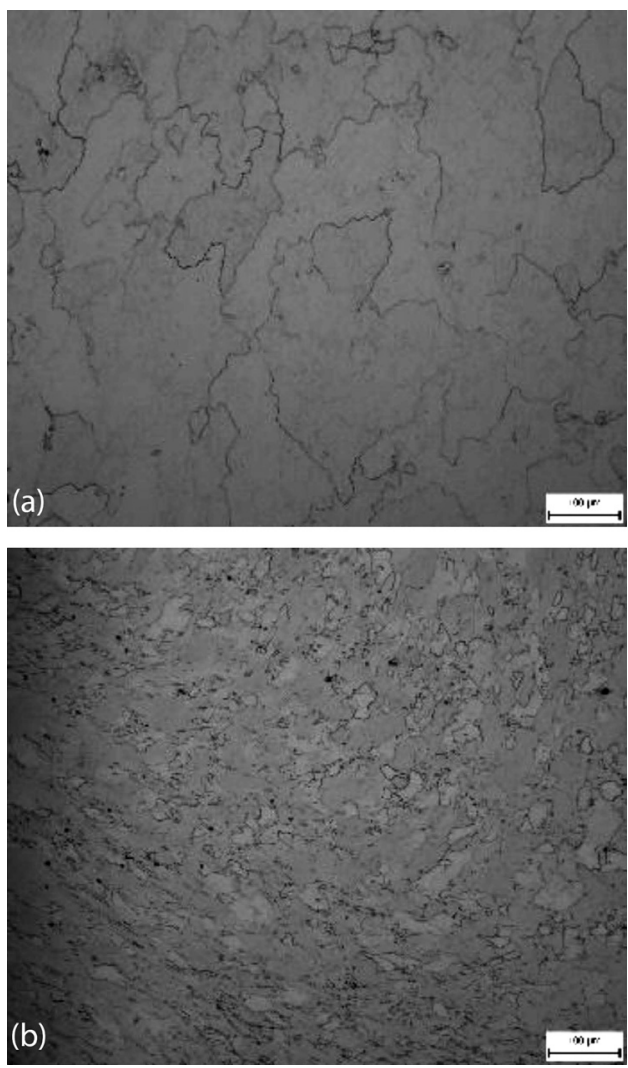

Figure 11: Microstructure for material 2 after $10 \mathrm{~h}$ annealing: a) without deformation, b) with $50 \%$ deformation
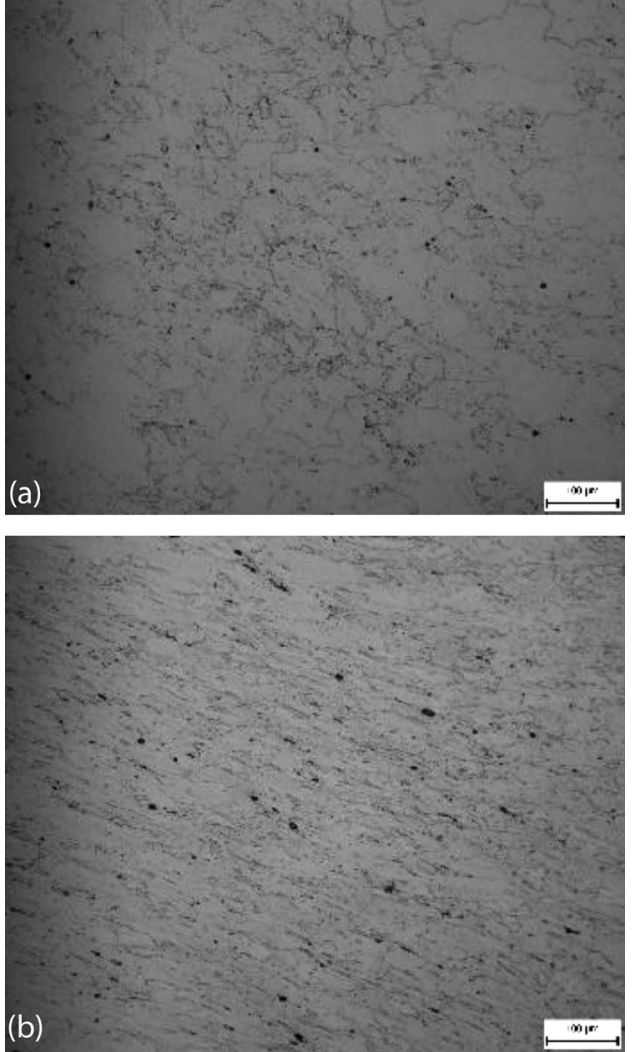

Figure 12: Microstructure for material 1 after $20 \mathrm{~h}$ annealing: a) without deformation, b) with $50 \%$ deformation
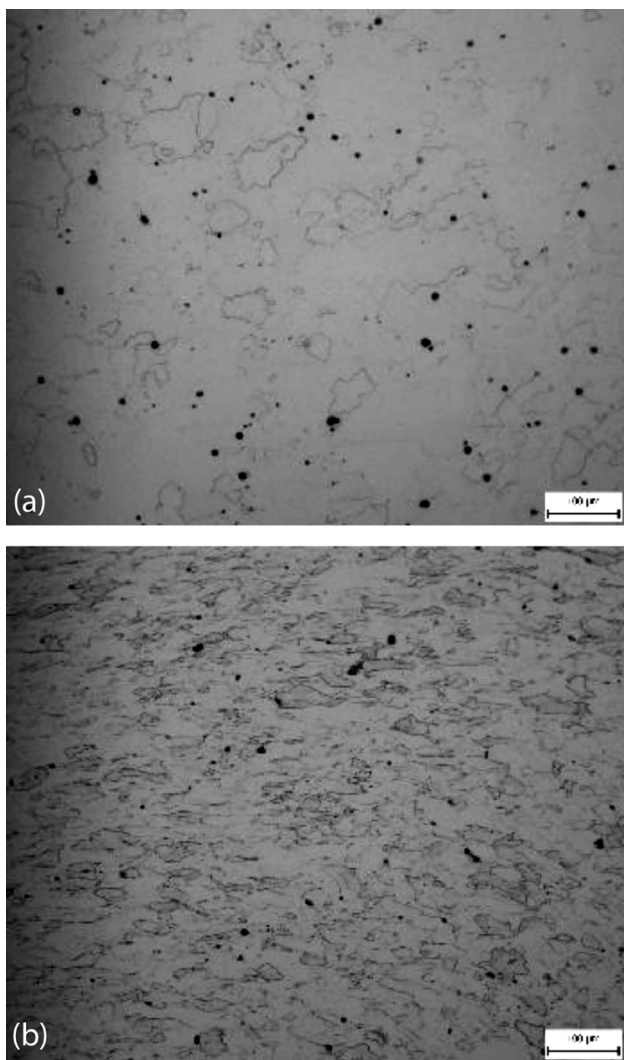

Figure 13: Microstructure for material 2 after $20 \mathrm{~h}$ annealing: a) without deformation, b) with $50 \%$ deformation 

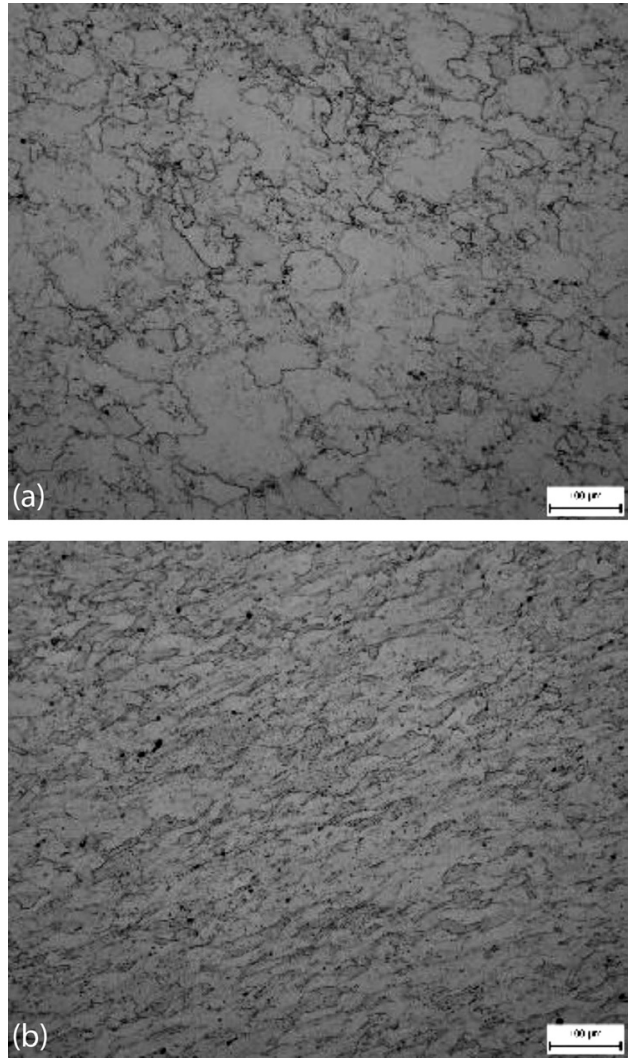

Figure 14: Microstructure for material 1 after $40 \mathrm{~h}$ annealing: a) without deformation, b) with $50 \%$ deformation
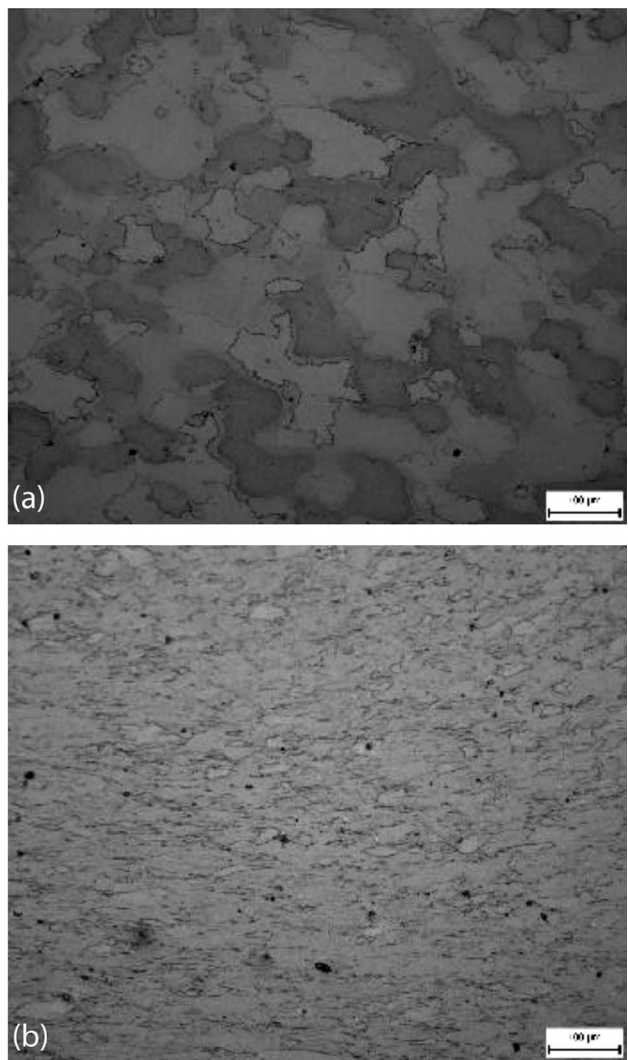

Figure 15: Microstructure for material 2 after $40 \mathrm{~h}$ annealing: a) without deformation, b) with $50 \%$ deformation sists of the $\mathrm{Fe}-\mathrm{Al}$ solid solution, iron aluminide and dispersed $\mathrm{Al}_{2} \mathrm{O}_{3}$. The grains of the solid solution are enclosed in black envelopes. The particles of $\mathrm{Al}_{2} \mathrm{O}_{3}$ are distributed throughout the structures. The influence of deformation is very obvious in the structures with the $50 \%$ deformation. The grains are elongated and there are also subgrains.

Figure 16 gives an overview of the grain sizes for both materials with different deformations and annealing times. The grain-size measurement was done according to ASTM E112. The grain size was measured using the intersection method for the longitudinal and transverse directions. Both values were then averaged and reported as the average grain size. It can be seen that both materials are almost recrystallized with a decrease in the grain size due to the increased deformation. It is obvious that with a higher deformation applied, the grain size decreases significantly. In material 1 , it decreases by almost $16 \%$ with the change from 0 to $8 \%$ of the applied deformation. Moreover, it decreases by almost $31 \%$ with the change from 8 to $50 \%$ at all the annealing times. Similarly, material 2 shows an almost $13 \%$ decrease in the grain size with the change from 0 to $8 \%$ and a $38 \%$ decrease in the grain size with the change from $8 \%$ to $50 \%$. On the other hand, with a constant deformation and increased holding time up to $20 \mathrm{~h}$, the average grain size increases slightly. However, with the increase of the annealing time from $20 \mathrm{~h}$ to $40 \mathrm{~h}$, it remains almost constant or decreases with some deformations. It can thus be concluded that the stability of the grain microstructure can be significantly influenced by the processing. The 20-h annealing is considered to be the optimum holding time, leading to the maximum
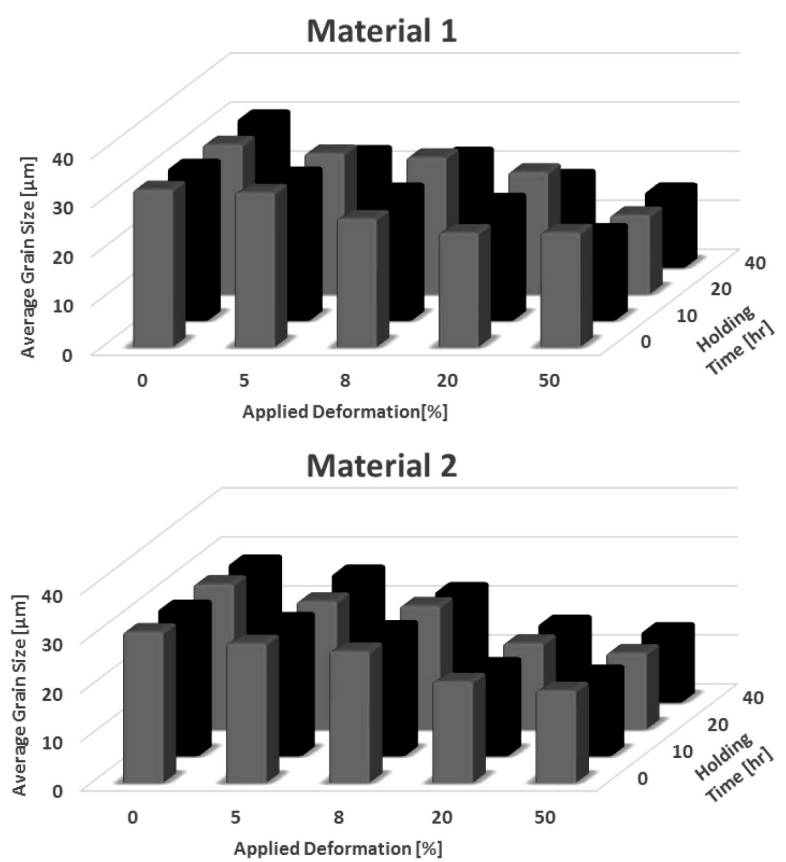

Figure 16: Average grain size for: a) material 1, b) material 2 
grain growth in the ODS materials investigated in this research.

\section{CONCLUSIONS}

This paper outlines the influence of thermomechanical treatments on the microstructure and grain growth of new $\mathrm{Fe}-\mathrm{Al}$ based alloys with fine $\mathrm{Al}_{2} \mathrm{O}_{3}$ precipitates. Two materials differing in the rolling process were tested under different conditions. The advantages of both materials are the simplicity of preparation, a low cost of the basic material and good mechanical and microstructural properties due to the Fe-Al based ferritic matrix of the ODS alloy. The results show that there is a significant reduction in the UTS with the temperature increase from RT to $800{ }^{\circ} \mathrm{C}$; however, there is no change in the elongation. With the temperature increase from $800{ }^{\circ} \mathrm{C}$ to $1200{ }^{\circ} \mathrm{C}$, there is no significant change in the UTS; however, the elongation decreases significantly. The holding time and applied deformation have almost no effect on the hardness of either material; however, they influence the average grain size of both materials. A higher deformation leads to a smaller grain size, while an increase in the annealing time up to $20 \mathrm{~h}$ leads to an increase in the average grain size of the ODS material.

\section{Acknowledgements}

This paper includes the results created within project 17-01641S Improvement of Properties and Complex Characterization of New Generation Fe-Al-O Based Oxide Precipitation Hardened Steels subsidised by the Czech Science Foundation from the specific resources of the state budget of the Czech Republic for research and development.

\section{REFERENCES}

${ }^{1}$ M. Mohan, R. Subramanian, Z. Alam, P. C. Angelo, Evaluation of the Mechanical Properties of a Hot Isostatically Pressed Yttria-Dispersed Nickel-Based Superalloy, Materials and technology, 48 (2014) 6, 899-904

${ }^{2}$ W. Quadakkers, Oxidation of ODS alloys, Journal de Physique IV, 03 (1993) C9, 177- 186, doi:10.1051/jp4:1993916

${ }^{3}$ F. Pedraza, Low Energy-High Flux Nitridation of Metal Alloys: Mechanisms, Microstructures and High Temperature Oxidation Behaviour, Mater. Tehnol., 42 (2008) 4, 157-169

${ }^{4}$ F. Savart, Researches on the elasticity of regularly crystallized bodies, The Edinburgh Journal of Science, 1 (1829), 141-7

${ }^{5} \mathrm{~F}$. Savart, Researches on the structure of metals, as indicated by their acoustic properties, The Edinburgh Journal of Science, 2 (1829), 104-11
${ }^{6}$ H. C. Sorby, On the microscopic structures of iron and study of microscopic structures of steel, Journal of Iron and Steel Instrumentation, 1 (1886), 140

${ }^{7}$ F. D. Fischer, J. Svoboda, P. Fratzl, A thermodynamic approach to grain growth and coarsening, Philosophical Magazine, 83 (2003) 9, 1075-1093, doi:10.1080/0141861031000068966

${ }^{8}$ O. Khalaj, B. Mašek, H. Jirkova, A. Ronesova, J. Svoboda, Investigation on New Creep and Oxidation Resistant Materials, Mater. Tehnol., 49 (2015) 4, 173-179, doi:10.17222/mit.2014.210

${ }^{9}$ M. J. Alinger, G. R. Odette, D. T. Hoelzer, On the role of alloy composition and processing parameters in nanocluster formation and dispersion strengthening in nanostuctured ferritic alloys, Acta Materialia, 57 (2009) 2, 392-406, doi:10.1016/j.actamat.2008.09.025

${ }^{10}$ P. Unifantowicz, Z. Oksiuta, P. Olier, Y. de Carlan, N. Baluc, Microstructure and mechanical properties of an ODS RAF steel fabricated by hot extrusion or hot isostatic pressing, Fusion Engineering and Design, 86 (2011), 2413-2416, doi:10.1016/j.fusengdes.2011.01.022

${ }^{11}$ M. A. Auger, V. de Castro, T. Leguey, A. Muñoz, R. Pareja, Microstructure and mechanical behavior of ODS and non-ODS $\mathrm{Fe}-14 \mathrm{Cr}$ model alloys produced by spark plasma sintering, Journal of Nuclear Materials, 436 (2013) 5, 68-75, doi:10.1016/j.jnucmat. 2013.01.331

${ }^{12}$ M. Kos, J. Ferces, M. Brnucko, R. Rudolf, I. Anzel, Pressing of Partially Oxide-Dispersion-Strenghtened Copper Using the ECAP Process, Mater. Tehnol., 48 (2014) 3, 379-384

${ }^{13}$ B. Mašek, O. Khalaj, Z. Nový, T. Kubina, H. Jirkova, J. Svoboda, C. Štádler, Behaviour of New ODS Alloys under Single and Multiple Deformation, Mater. Tehnol., 50 (2016) 6, 891-898, doi:10.17222/ mit.2015.156

${ }^{14}$ P. Marmy, T. Kruml, Low cycle fatigue of Eurofer 97, Journal of Nuclear Materials, 377 (2008) 1, 52-58, doi:10.1016/j.jnucmat. 2008.02.054

${ }^{15}$ M. Misovic, N. Tadic, M. Jacimovic, M. Janjic, Deformations and Velocities during the Cold Rolling of Aluminium Alloys, Mater. Tehnol., 50 (2016) 1, 59-67, doi:10.17222/mit.2014.250

${ }^{16}$ A. Grajcar, Microstructure Evolution of Advanced High-Strength Trip-Aided Bainitic Steel, Mater. Tehnol., 49 (2015) 5, 715-720, doi:10.17222/mit.2014.154

${ }^{17}$ B. Sustarsic, I. Paulin, M. Godec, S. Glodez, M. Sori, J. Flasker, A. Korosec, S. Kores, G. Abramovic, DSC/TG of Al-Based Alloyed Powders for P/M Applications, Mater. Tehnol., 48 (2014) 4, 439-450

${ }^{18}$ O. Khalaj, B. Mašek, H. Jirková, D. Bublíková, J. Svobodá, Influence of Thermomechanical Treatment on Grain Growth Behaviour of New Fe-Al Based Alloys with fine $\mathrm{Al}_{2} \mathrm{O}_{3}$ Precipitates, Mater. Technol., 51 (2017) 5, 759-768, doi:/10.17222/mit.2016.232

${ }^{19}$ A. Kocijan, I. Paulin, C. Donik, M. Hocevar, K. Zelic, M. Godec, Influence of Different Production Progresses on the Biodegradability of AN FeMn17 Alloy, Materials and technology, 50 (2016) 5 , 805-811, doi:10.17222/mit.2016.055

${ }^{20}$ D. Kumar, U. Prakash, V. V. Dabhade, K. Laha, T. Sakthivel, High yttria ferritic ODS steels through powder forging, Journal of Nuclear Materials, 488 (2017), 75-82, doi:10.1016/j.jnucmat.2016.12.043

${ }^{21}$ L. Straßberger, D. Litvinov, J. Aktaa. High temperature tensile properties of oxide dispersion strengthened T91 and their correlation with microstructural evolution, Materials Science and Technology, 30 (2014) 13, 1691-1696, doi:10.1179/1743284714Y.0000000562

${ }^{22}$ H. Dong, L. Yu, Y. Liu, Ch. Liu, H. Li, J. Wu, Enhancement of tensile properties due to microstructure optimization in ODS steels by zirconium addition, Fusion Engineering and Design, 125 (2017), 402-406, doi:10.1016/j.fusengdes.2017.03.170 